\title{
Intestinal Parasites in Free-Living Puma concolor
}

\author{
Marco Aurélio Cunha Del Vechio', Edson Gerônimo', Enzo Emmerich Paula de Castro, \\ Luciana Vieira Pinto Ribeiro², Rita de Cássia Lima Ribeiro², Reinaldo José da Silva ${ }^{3}$, \\ Daniela Dib Gonçalves' \& Lidiane Nunes Barbosa'
}

\begin{abstract}
Background: Studies on intestinal parasites in cougars Puma concolor are scarce, and most of the available information on the species has been derived from individuals in captivity. One of the greatest threats to the survival of wild cats is habitat loss caused by urban sprawl, agricultural matrix, and linear developments such as highways and railways, which expose animals to direct contact with humans and to a high risk of death. Given the lack of scientific data the objective of this study was to report on the occurrence of intestinal parasites in a cougar ( $P$. concolor) specimen from the northwestern region of Paraná State, Brazil.

Case: The carcass of a free-living cougar (P. concolor) individual was sent to the Interdisciplinary Science Museum (Museu Interdisciplinar de Ciências - MIC) of Paranaense University (Universidade Paranaense - UNIPAR); an individual was killed during a collision with an unidentified vehicle on highway PR-486, in the municipality of Mariluz (PR, Brazil). The geographical coordinates of the location where the animal was found are: $23^{\circ} 59^{\prime} 29^{\prime \prime} \mathrm{S}, 53^{\circ} 8^{\prime} 47^{\prime \prime} \mathrm{W}$. This region is characterized by semi-deciduous seasonal forest remnants. After being identified on site and collected by the inspectors of the Paraná Environmental Institute (Instituto Ambiental do Paraná - IAP), the cadaver was donated to the MIC (by the IAP) for a necropsy to elucidate the cause of death. In this context, the cadaver was sent to the Animal Pathology section of the Department of Veterinary Medicine at UNIPAR. The animal was necropsied by performing the standard necropsy technique for carnivores: opening the intestine through the mesentery and exposing the mucosa from the duodenum to the colon. The necropsy showed that the cause of death was hypovolemic shock due to trauma. During necropsy, parasites in the intestinal lumen were visible to the naked eye. Parasites and feces were collected and stored in sterile flasks containing $10 \%$ formaldehyde and saline. The parasites were subjected to Faust and Hoffman techniques, micrometry, and morphological analysis, resulting in the identification of the roundworm Toxocara cati and the tapeworm Spirometra decipiens.

Discussion: Identifying the roadkill species along highways is of paramount importance, since they are living very close to man and, consequently, reservoirs and disseminators of different infectious and parasitic zoonoses may be possible. Infection by protozoa and helminths in animals usually occurs by ingesting the infective form present in food or water. Toxocara cati and the tapeworm Spirometra decipiens were only reported in captivity before. Research on parasites in free-living wild animals is not common in the scientific literature and this is due to the difficulty of capturing this animal category as they live in difficult to access places such as forests and forests, therefore, research projects in partnership with museums are extremely important for the recognition of wild animal species that circulate in the region, in addition to the parasitic identification of these animals for future sanitary measures and for the preservation of the animal species in the environment. The Parasitological studies of wild animals are highly relevant for expanding this knowledge, especially considering the possible transfer risk of specific parasitic diseases to other animals, as well as to humans.
\end{abstract}

Keywords: wild animals, feces, diagnosis, cougar, zoonosis. 


\section{INTRODUCTION}

The cougar Puma concolor is the most widespread terrestrial mammal in the neotropical region $[8,26,36]$, it is a solitary, territorial carnivore similar among many other species of felids, although it may manifest itself differently for males and females [36]. In Brazil, the cougar is found in all biomes [27] and inhabits different types of environments [7].

Animal mortality on Brazilian highways has been increasing due to deforestation and habitat fragmentation, which have been directly linked to wildlife roadkill $[23,34]$.

Studies on intestinal parasites in the cougar $(P$. concolor) are scarce, and most of the available information on the species has been derived from individuals in captivity $[4,15,25,28,29,39]$. In general, intestinal parasites, especially helminths, are not indicated as the cause of death in wildlife, although they may cause changes in behavior, reproductive and nutrient uptake.
These changes may render individuals more vulnerable to other environmental pressures [3].

Given the lack of scientific data, and the concern about the role of wild cats in the transmission of parasitic diseases to humans and other animal species, the objective of this study was to detect and identify intestinal parasites in the feces of a cougar ( $P$. concolor) roadkill on a highway in the northwestern region of Paraná State, Brazil.

\section{CASE}

The carcass of a free-living cougar ( $P$. concolor) individual was sent to the Interdisciplinary Science Museum (Museu Interdisciplinar de Ciências - MIC) of Paranaense University (Universidade Paranaense UNIPAR); an individual was killed during a collision with an unidentified vehicle on highway PR-486, in the municipality of Mariluz (PR, Brazil). The geographical coordinates of the location where the animal

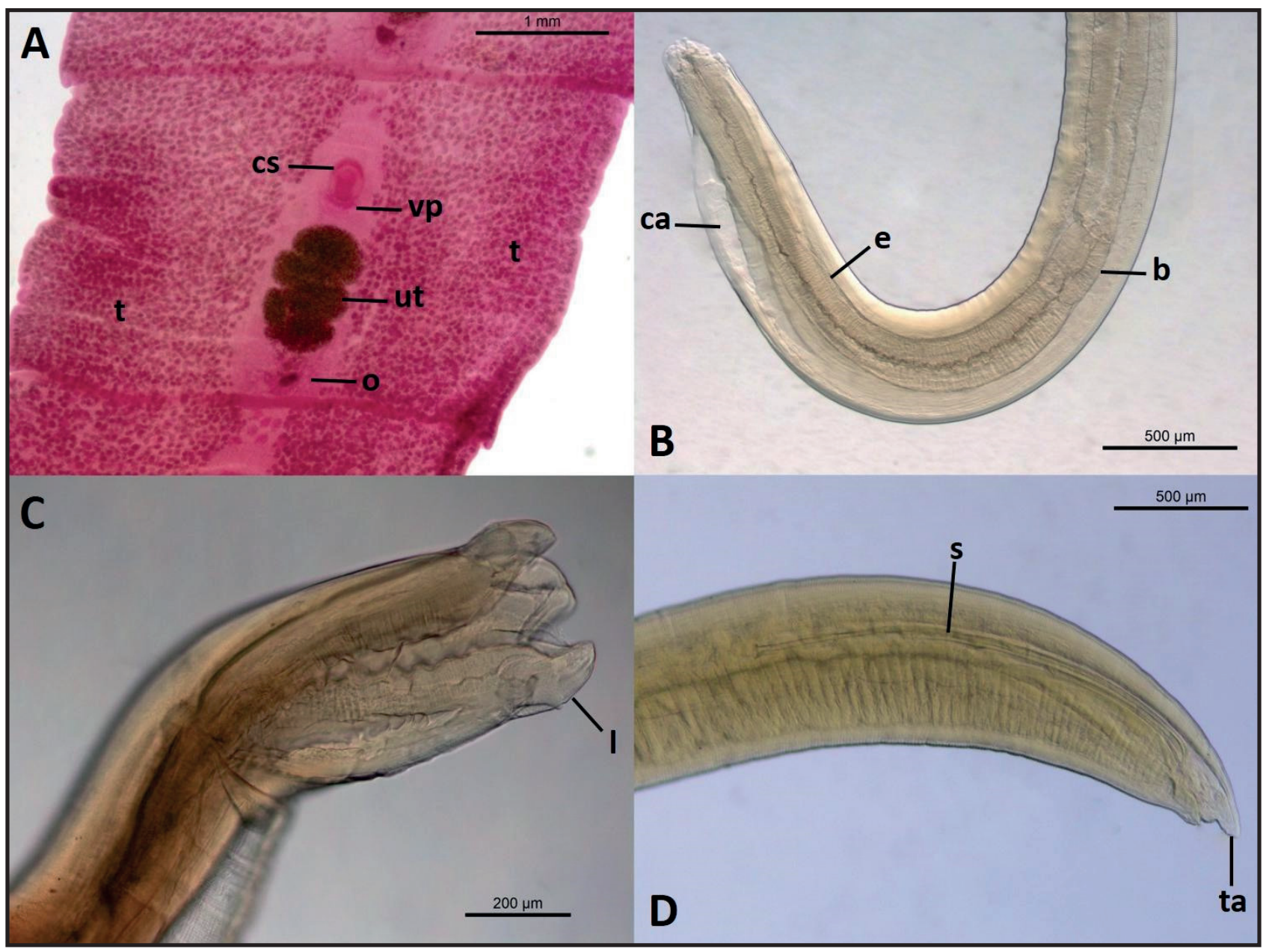

Figure 1. Helminths recovered in Puma concolor from Paraná State. A- Spirometra decipiens. cs: cirrus sac; vp: vaginal pore; ut: uterus; o: ovary; t: testes [Carmine stain]. B-D- Toxocara cati. Lactophenol clarification. B- Anterior end. ca: cephalic alae; e: esophagus; b: bulb esophagic. C- Detail of lips (1); D- Posterior end. s: spicule, ta: tail. 
was found are: $23^{\circ} 59^{\prime} 29^{\prime \prime} \mathrm{S}, 53^{\circ} 8^{\prime} 47^{\prime \prime} \mathrm{W}$. This region is characterized by semi-deciduous seasonal forest remnants. After being identified on site and collected by the inspectors of the Paraná Environmental Institute (Instituto Ambiental do Paraná - IAP), the cadaver was donated to the MIC (by the IAP) for a necropsy to elucidate the cause of death. In this context, the cadaver was sent to the Animal Pathology section of the Department of Veterinary Medicine at UNIPAR.

The cougar was a male weighing $65 \mathrm{~kg}$. The animal measured $75 \mathrm{~cm}$ from cervical vertebrae to sacrum and $30 \mathrm{~cm}$ from nose to nape with a $50 \mathrm{~cm}$ skull circumference and a $65 \mathrm{~cm}$ long tail. The forelimbs measured $35 \mathrm{~cm}$ in length, whereas the hindlimbs measured $42 \mathrm{~cm}$. The chest circumference measured $90 \mathrm{~cm}$, and the total length of the animal from nose to tail-tip was $1.70 \mathrm{~m}$. The age was determined based on [2] photographic guide, characterizing the Puma as a young adult, from 3 to 4 years old. Its fur was beige on the back, with lighter, almost white, ventral regions.

The animal was necropsied at the Veterinary Hospital of UNIPAR by performing the standard necropsy technique for carnivores: opening the intestine through the mesentery and exposing the mucosa from the duodenum to the colon. The necropsy showed that the cause of death was hypovolemic shock due to trauma. During necropsy, parasites in the intestinal lumen were visible to the naked eye. Parasites and feces were collected and stored in sterile flasks containing $10 \%$ formaldehyde $\left(\text { EMSURE }^{\circledR}\right)^{1}$ and saline.

The collected material was subjected to the zinc sulphate centrifugal flotation method and to spontaneous sedimentation $[11,17]$. To identify the parasites, the collected roundworms were clarified in lactophenol, and the tapeworms were stained with acetic carmine and diaphanized in creosote [1], followed by micrometry and morphological analysis. The helminths were identified under a microscope with differential interference contrast optics (Leica DMLB 5000, Leica Microsystems) $)^{2}$.

Parasitological analysis identified the roundworm Toxocara cati and the tapeworm Spirometra decipiens (Figure 1). The identification of T. cati (n $=2$ ) was confirmed by the cephalic alae, mouth with three fleshy lips without interlips, esophagus ending in a ventricle, digitiform appendix at the male tail and, especially, by the size of the spicule, which was 1.70 mm [31,38,39]. Spirometra decipiens was identified base on [21], who characterized the species by its small, spoon-shaped scolex with two distinct bothria, mature proglottids, uterus with 3-4 turns and ball-shape at the end, crescent-moon-shaped vaginal opening located closer to the cirrus opening than to the uterine pore, and genital pore ventrally located in the midline in the $1 / 5$ anterior of the proglottids.

\section{DISCUSSION}

The parasite Toxocara cati was identified in fecal samples from this road killed animal. The results of this study corroborate the findings in Washington (USA) [33], which T. cati was one of the two parasites detected in two free-living cougars (P. concolor). However, differing results were found in Rio Grande do Sul (RS) [10] when studying a cougar in captivity; the results showed a mixed infection of Cryptosporidium sp. oocysts, Trichuris sp. eggs, and oocysts suggestive of Toxoplasma gondii or Besnoitia sp. In Belize, Central America, [29] studied parasites in jaguar (Panthera onca), Jaguarundi (Puma yagouaroundi), jaguatirica (Leopardus pardalis) and puma (P. concolor) feces; they detected and identified eggs of Paragonimus sp., Taeniidae, Strongylus sp., Toxocara cati, Toxascaris sp., Capillaria sp., Spiruridae, Oncicola sp., larvae of Aelurostrongylus sp., oocusts from Hammondia pardalis, Isospora sp., Toxoplasma gondii, and Sarcocystis sp. sporocysts.

Another parasite identified during necropsy was Spirometra decipiens, which is commonly found in cats and dogs in Asia and has been shown to be transmitted to humans $[18,19]$. Molecular identification of this parasite in humans [18] and snakes [20] has been reported in the literature, in addition to being on the list of helminths known to be present in wild carnivores of Brazil [39], however, no reports or research studies identifying this parasite in large cats were found in the literature. In a study conducted with 19 species of mammals [14], 11 showed some type of egg and/ or oocyst in feces, including: capybara, collared peccary, white-lipped peccary, giant anteater, ocelot, cougar, and jaguar.

Highways improve access to farming areas, promoting job creation, income distribution, and tourism, which in turn increase land value and contribute to the quality of life and the social and economic development of a region [12,30]. However, similar to any human enterprise that alters an ecosystem, highways have negative environmental impacts resulting from 
the fragmentation of natural areas, which is currently recognized as one of the main threats to biodiversity conservation $[6,22]$.

In Brazil, studies on the impact of highways on wildlife roadkill have been conducted in different Brazilian states. Studies in Goiás (GO) [32], Rio Grande do Sul (RS) [37] and Minas Gerais (MG) [35], reported 141 wild animal species and one roadkill for every 19.2 $\mathrm{km}$ of highway, 27 species and one roadkill for every $6.8 \mathrm{~km}$, and 32 species and one roadkill for every 13 $\mathrm{km}$, respectively. These studies have only quantified wildlife roadkill and identified roadkill species on highways. However, the health status of these animals must be studied because they live in close proximity to humans and therefore can be reservoirs and disseminators of different infectious and parasitic zoonoses.

In this study, an unidentified vehicle immediately roadkill a cougar (P. concolor) on a highway of the northwestern region of Estado do Paraná State, Brazil. Several authors have reported that animal species are roadkilled on highways due to habitat fragmentation, which interferes with the natural species movement, and due to the presence of food along highways, which attracts the animals $[5,6,13]$.

Ecological changes can increase the contact between pathogen species and new host populations, and natural selection pressures can in turn promote the occurrence of dominant pathogens adapted to these new environmental conditions [9]. This may render wildlife epidemics caused by parasites from domestic animals increasingly more common [16]. One of the main benefits of an efficient wildlife disease-monitoring program is the early detection of new or emerging diseases, some of which may have serious zoonotic and economic implications [24].

Therefore, research projects conducted in partnership with museums are extremely important as they document wildlife species moving in the region and can enable identification of parasites in those animals; these data can be useful for future health and environmental preservation measures.

Studies on mammalian parasites in Brazil began in 1648 , however, despite this long history, there are few studies on their diversity. Studies on the intestinal parasites of free-living cats are highly relevant for increasing our knowledge of the biology of these animals and their relationships with the environments they inhabit [38].

\section{MANUFACTURERS}

${ }^{1}$ Merck S.A. Rio de Janeiro, RJ, Brazil.

${ }^{2}$ Leica do Brasil Importação e Comércio Ltda. São Paulo, SP, Brazil.

Acknowledgements. We are thankful to Paranaense University (Universidade Paranaense - UNIPAR) and to the Araucaria Foundation (Fundação Araucária) for funding this research, the Coordination for the Improvement of Higher Education Personnel (Coordenação de Aperfeiçoamento de Pessoal de Nível Superior - CAPES) for the Graduate Support Program for Private Education Institutions (Programa de Suporte à PósGraduação de Instituições de Ensino Particulares - PROSUP) tuition fees, and the inspectors of the Paraná Environmental Institute (Instituto Ambiental do Paraná - IAP) for their constant collaboration with the Interdisciplinary Science Museum (Museu Interdisciplinar de Ciências - MIC) of UNIPAR.

Declaration of interest. The authors report no conflicts of interest. The authors alone are responsible for the content and the writing of this paper.

\section{REFERENCES}

1 Amato J.F.R., Boeger W.A. \& Amato S.B. 1991. Protocolos para laboratório: coleta e processamento de parasitos de pescado. Seropedica: UFRRJ, 81p.

2 Anderson C.R. \& Lindzey F.G. 2000. A photographic guide to estimating mountain lion age classes. Laramie: Wyoming Cooperative Fish and Wildlife Research Unit, 2p.

3 Anderson R.C. 1976. Helminths. In: Page L.A. (Ed). Wildlife Diseases. Boston: Springer, pp.35-43.

4 Brandão M.L., Chame M., Cordeiro J.L.P. \& Chaves S.A.M. 2009. Diversidade de helmintos intestinais em mamíferos silvestres e domésticos na Caatinga do Parque Nacional Serra da Capivara, Sudeste do Piauí, Brasil. Revista Brasileira Parasitologia Veterinária. 18(1): 19-28.

5 Clevenger A.P., Chruszcz B. \& Gunson K. 2003. Spatial patterns and factors influencing small vertebrate fauna roadkill aggregations. Biological Conservation. 109(1): 15-26.

6 Coffin A.W. 2007. From roadkill to road ecology: a review of the ecological effects of roads. Journal of Transport Geography. 15(5): 396-406.

7 Culver M. 2010. Lessons and insights from evolution, taxonomy and conservation genetics. In: Hornocker MG \& Sharon N. (Eds). Cougar: ecology and conservation. Chicago: The University of Chicago Press, pp.27-40. 
8 Currier M.J. 1983. Felis concolor. Mammalian Species. 200: 1-7.

9 Daszak P., Cunningham A.A. \& Hyatt A.D. 2001. Anthropogenic environmental change and the emergence of infectious diseases in wildlife. Acta Tropica. 78(2): 103-116.

10 Fanfa V., Farret M., Da Silva A.S. \& Monteiro S. 2011. Endoparasitoses em puma (Puma concolor) na região Sul do Brasil. Acta Veterinaria Brasilica. 5(1): 100-102.

11 Faust E.C., Russell P.F. \& Jung R.C. 1970. Craig and Faust's Clinical Parasitology. 8th edn. Philadelphia: La Febiger, $177 \mathrm{p}$.

12 Fearnside P.M. 1990. The rate and extent of deforestation in Brazilian Amazonia. Environmental Conservation. 17(3): 213-226.

13 Forman T.T.R. \& Alexander L.E. 1998. Roads and their major ecological effects. Annual Review of Ecology and Systematics. 29: 207-231.

14 Franceschini L., Seno M.C.Z. \& Zago A.C. 2007. Levantamento parasitológico dos mamíferos do centro de conservação da fauna silvestre de Ilha Solteira - SP. 4f. São Paulo, SP. Tese (Ciências Biológicas) - Faculdade de Ciência Biológicas, Universidade Estadual Paulista.

15 Freitas M.V.M. 2011. Levantamento de parasitos intestinais e pulmonares de felídeos e canídeos silvestres da Fundação Zoo-Botânica de Belo Horizonte por meio de técnicas coprológicas. 224f. Mato Grosso do Sul, MS. Monografia (Conclusão do Curso de Especialização em Clínica Médica e Cirúrgica de Animais Selvagens e Exóticos) - Centro Universitário da Grande Dourados.

16 Funk S.M., Fiorello C.V., Cleaveland S. \& Gompper M.E. 2001. The role of disease in carnivore ecology and conservation. In: Gittleman J.L., Funk S.M., Macdonald D. \& Wayne R.K. (Eds). Carnivore Conservation, Conservation Biology 5. United Kingdom: Cambridge University Press, pp.443-466.

17 Hoffman W.A., Pons J.A. \& Janer J.L. 1934. The sedimentation concentration method in schistosomiasismansoni. Journal of Public Health and Tropical Medicine. 9: 283-298.

18 Jeon H.K., Park H., Lee D., Choe S., Kim K.H., Sohn W.M. \& Eom K.S. 2015. Human infections with Spirometra decipiens plerocercoids identified by morphologic and genetic analyses in Korea. The Korean Journal of Parasitology. 53(3): 299-305.

19 Jeon H.K., Park H., Lee D., Choe S., Kim K.H., Sohn W.M. \& Eom K.S. 2016. Molecular detection of Spirometra decipiens in the United States. The Korean Journal of Parasitology. 54(4): 503.

20 Jeon H.K., Park H., Lee D., Choe S., Kim K.H., Sohn W.M. \& Eom K.S. 2016. Genetic identification of Spirometra decipiens plerocercoids in terrestrial snakes from Korea and China. The Korean Journal of Parasitology. 54(2): 181.

21 Jeon H.K., Park H., Lee D., Choe S., Kim K.H., Sohn W.M. \& Eom K.S. 2018. Spirometra decipiens (Cestoda: Diphyllobothriidae) Collected in A Heavily Infected Stray Cat from the Republic of Korea. The Korean Journal of Parasitology. 56(1): 87-91.

22 Laurance W.F., Goosem M. \& Laurance S. 2009. Impacts of roads and linear clearings on tropical forests. Trends in Ecology \& Evolution. 24(12): 659-669.

23 Meneguetti D.U.O., Meneguetti N.F.S.P. \& Trevisan O. 2010. Georreferenciamento e reavaliação da mortalidade por atropelamento de animais silvestres na linha 200 entre os municípios de Ouro Preto do Oeste e Vale do Paraíso - RO. Revista Científica da Faculdade de Educação e Meio Ambiente. 1(1): 58-64.

24 Mörner T., Obendorf D.L. \& Artois M. 2002. Surveillance and monitoring of wildlife diseases. Revue Scientifique et Technique (Internacional Office of Epizootics). 21(1): 67-76.

25 Müller G.C.K., Greinert J.A. \& Silva Filho H.H. 2005. Frequência de parasitas intestinais em felinos mantidos em zoológicos. Arquivo Brasileiro de Medicina Veterinária e Zootecnia. 57(4): 559-561.

26 Nowak R.M. 2005. Walker's carnivores of the World. 6th edn. Maryland: The Johns Hopkins University Press, 313p.

27 Oliveira T.G. 1994. Neotropical cats: ecology and conservation. São Luís: EDUFMA, 244p.

28 Otto G.F. 1974. Occurrence of the heartworm in unusual locations and in unusual hosts. In: American Heartworm Society proceedings of the Heartworm Symposium. Bonner Springs: VM Publishing Co, pp.6-13.

29 Patton S., Rabinowitz A., Randolph S. \& Johnson S. 1986. A coprological survey of parasites of wild neotropical Felidae. The Journal of Parasitology. 72(4): 517-520.

30 Perz S.G., Caldas M.M., Arima E. \& Walker R.J. 2007. Unofficial road building in the Amazon: socioeconomic and biophysical explanations. Development and Change. 38(8): 529-551. 
31 Poulsen C.S., Skov S., Yoshida A., Skallerup P., Maruyama H., Thamsborg S.M. \& Nejsum P. 2015. Differential serodiagnostics of Toxocara canis and Toxocara cati - is it possible? Parasite Immunology. 37(4): 204-207.

32 Prado T.R., Ferreira A. \& Guimarães Z.F.S. 2006. Efeito da implantação de rodovias no cerrado brasileiro sobre a fauna de vertebrados. Acta Scientiarum Biological Sciences. 28(3): 237-241.

33 Rickard L.G. \& Foreyt W.J. 1992. Gastrointestinal parasites of cougars (Felis concolor) in Washington and the first report of Ollulanus tricuspis in a sylvatic felid from North America. Journal of Wildlife Diseases. 28(1): 130-133.

34 Santana G.S. 2012. Fatores influentes sobre atropelamentos de vertebrados silvestres em rodovias da Região Central do Estado do Rio Grande do Sul, Brasil. Neotropical Biology and Conservation. 7(1): 26-40.

35 Santos A.L.P.G., Rosa C.A., Hobus Q., Passamani M. \& Bager A. 2009. Caracterização temporal dos atropelamentos de fauna selvagem na rodovia MG-354, sul de Minas Gerais - Brasil. In: Congresso Latino Americano de Ecologia. (São Paulo, Brasil). 4p.

36 Sunquist M.E. \& Sunquist F.C. 2002. Wild Cats of the World. Chicago: University Chicago Press, 452p.

37 Tonin A.M., Amaral B.T.C., Paier C. \& Oliveira C.H. 2009. Toxocara spp. infections in paratenic hosts. Veterinary Parasitology. 193(4): 375-89.

38 Vicente J.J., Rodrigues H.O., Gomes D.C. \& Pinto R.M. 1997. Nematóides do Brasil. Parte V: Nematóides de mamíferos. Revista Brasileira de Zoologia. 14(1): 1-452.

39 Vieira F.M., Luque J.L. \& Muniz-Pereira L.C. 2008. Checklist of helminth parasites in wild carnivore mammals from Brazil. Zootaxa. 1721: 1-23. 